\title{
Religious education can contribute to adolescent mental health in school settings
}

\author{
Crystal Amiel M. Estrada ${ }^{*}$, Marian Fe Theresa C. Lomboy², Ernesto R. Gregorio Jr. ${ }^{3}$, Emmy Amalia ${ }^{4}$, \\ Cynthia R. Leynes ${ }^{5}$, Romeo R. Quizon ${ }^{2}$ and Jun Kobayashi, ${ }^{1,6^{*}}$
}

\begin{abstract}
Background: Mental disorders contribute substantial burden to the society due to their widespread occurrence and debilitating effects. A quarter of the world's population are children and adolescents, a significant number of whom experience mental disorders as early as the age of 14 . Some interventions have been found to effectively reduce the risk factors and reinforce protective or preventive factors. However, there is still a need to put emphasis on mental health promotion strategies such as religious education. This paper aims to discuss the importance of religious education in promoting mental health.

Discussion: Religious education can be instrumental to improving adolescent mental health. Specifically, it can: (1) help develop healthier reaction to stimuli through the internalization of religious morality; (2) reinforce religious coping mechanisms which reduce the impact of stresses, enhance coping skills, and promote a less risky lifestyle; (3) increase awareness regarding religious beliefs and practices and their influence on the individual, the family, and the community; and finally, (4) promote connectedness which can enhance self-esteem and well-being. However, negative health outcomes such as discrimination and social isolation can also develop, especially among religious or gender minority groups.
\end{abstract}

Conclusion: It is important to reflect on the crucial role of religious education on adolescent mental health. Schoolbased mental health education and promotion strategies can maximize the benefits of religious education by putting emphasis on effective implementation of religious education to positively influence adolescent mental health.

Keywords: Religious education, Adolescent mental health, Schools

\section{Background}

Mental disorders are global public health concerns due to their widespread occurrences and debilitating effects. In 2010, mental, neurological, and substance abuse disorders accounted for 258 million disability-adjusted life years (DALYs), equivalent to $10.4 \%$ of global DALYs, $2.3 \%$ of global years of life lost (YLLs), and $28.5 \%$ of global years lived with disability (YLDs) [1]. The most recent estimates from the World Health Organization identified depressive disorders as the largest contributor to global YLD, accounting for 50 million or $7.5 \%$ of all YLDs [2].

\footnotetext{
*Correspondence: cmestrada@up.edu.ph; junkobalao@gmail.com

${ }^{1}$ Department of Global Health, School of Health Sciences, University

of the Ryukyus, Okinawa, Japan

Full list of author information is available at the end of the article
}

Adolescence is a critical period of cognitive and behavioral human development. According to Erik Erikson's Social-Emotional Development Theory, it is during this stage when an individual urgently needs to search for a proper role model to answer the big question of who he/ she is and his/her moral and spiritual aspects. This formation of identity is a major event in the development of personality and is associated with positive life outcomes [3]. Moreover, it is during this period when an individual develops the capacity to understand and internalize religion-its beliefs, values, and practices [4], which can lead to changes in the pattern of religious participation [5]. Furthermore, the emergence of mental disorders coincides with this developmental period, with an estimated half of mental disorders manifesting as early as 14 years old [6]. On a global scale, $10-20 \%$ of this population 
experience mental disorders, with depression contributing the largest burden of disease [3]. Poor mental health has been shown to affect the overall health and wellbeing of adolescents and is associated with adverse health and social outcomes like substance abuse, adolescent pregnancy, school drop-out, and delinquent behaviors, among others.

Mental disorders contribute substantial burden to the society. Given the magnitude of this public health problem, it is necessary to employ strategies which can effectively reduce its occurrence. Strategies which put emphasis on improving social determinants of health such as nutrition, housing, access to education, reductions in economic insecurity and harm from addictive substances, and strengthening of community networks have been found to reduce risks, reinforce protective factors, and decrease psychiatric symptoms and disability and the onset of some mental disorders [7]. School-based interventions are especially advantageous in addressing mental disorders, since children and adolescents spend more time in this setting than in any other formal institutions. Interventions implemented in schools which aim to improve adolescent mental health using strategies such as gatekeeper training and improving knowledge or mental health literacy among others are found to be effective in increasing knowledge, self-esteem, and social support thus reducing risk factors [8-10]; however, there is limited information on the integration of religious education in these interventions, which can be an effective approach in promoting mental health. This paper discusses religious education and how it can influence adolescent mental health.

\section{Discussion}

\section{Defining religious education}

Religious education aims to provide students with knowledge and understanding of, as well as to develop sensitivity to different religions [11]. Religious education has been traditionally categorized into: (a) confessional religious education, which seeks to promote obligation towards a specific religion, such as Islam [12], or Catholicism [13]; and (b) non-confessional religious education, which focuses on providing information about religion/ religions for students to expand their understanding on the different worldviews and eventually result in the development of tolerance for other religions [14]. Confessional religious education is implemented in countries such Austria and Croatia, while non-confessional religious education is present in Slovenia [15]. Education is crucial to the development of a tolerant society. The education system in many countries have evolved from being secular to one that promotes pluralism, an understanding that people will have different conceptions of the good and understanding of the best way to live life morally [16]. In the United States, for example, public education was designed to teach Protestant values. However, the increase in the Catholic population has led to the instruction of religion as a subject matter without any intention of indoctrination. Religious education remains a topic for debate because of the inviolable separation of the Church and State in some countries [17]. Nevertheless, teaching religion in secular schools can provide a student with deeper understanding of different cultures around the world, enrich a student's understanding of human experiences, and allow the student to acquire values that they can integrate into their own lives [18].

\section{Adolescence and religion}

Adolescence is the stage of human development which Erik Erikson states as a transition period from childhood to adulthood. An integral component of this developmental stage is identity development, wherein an individual develops the ability to think about abstract concepts and the capacity to think about the consequences of decisions that they make. This developmental stage is also characterized by an increase in their sense of autonomy, leading to more interaction with peers and other individuals [3]. These changes that occur in adolescents affect their view about religion and its accompanying beliefs and practices. In their quest to develop their identity, they start searching for life's meaning and become critical of ideologies being taught in religion. Consequently, adolescents question or reject some religious ideas which were taught to them by adults during early age [19]. Experiences and interaction with others during this developmental period are also critical in the development of religiosity. For example, family structure and attachment influence how religious behaviors and attitudes are transmitted from parents to their children; adolescents who were raised by both parents and grew up in families with close relationships are more likely to adopt their parents' religious beliefs and practices [20]. Similarly, peers influence adolescent religiosity in the sense that religiosity fosters greater peer attachment; that is, religious adolescents tend to have more friends who foster the same religious belief and they are less likely to engage in delinquent behavior [21].

The role of religious education in adolescent mental health Religion and its effect on health and well-being has been the subject of many previous studies [22]. Although the definitions for both religiosity and spirituality remains a point of debate among researchers, the two concepts are considered as related [23] and include several dimensions such as beliefs, attitudes, and behaviors, to name a few [24]. A recent systematic review and meta-analysis 
of randomized controlled trials which investigated the effects of religious and spiritual interventions showed positive effects on mental health outcomes such as significant decrease in stress, alcoholism, and depression [25]. However, the importance of religious education in the promotion of both physical and mental health in the school has not been given emphasis despite several religions teaching about overall health and well-being. For example, Islam teaches the importance of personal hygiene, stress management, and eating healthy [26]; Buddhism teaches avoidance of any drink or drug which can cloud the mind [27]; the Catholic Christian spiritual perspective puts emphasis on confession of sins for forgiveness by God to provide relief to a troubled mind; and Jewish beliefs emphasize that their bodies belong to God and should therefore take care of it by maintaining a proper diet, getting adequate exercise and sleep, maintaining good hygiene, and having a healthy mind [28].

One of the basic aims of religious education is to promote awareness about religious beliefs and practices and how these affect the individual, the family, and the community [29]. Previous studies have presented evidence of the positive effects of religious education against risky health behaviors such as alcohol use, drug use, violence [30], and suicidal ideation [31]. Religious education can be instrumental to improving adolescent mental health by developing religious morality, reinforcing religious coping, developing respect for religious diversity, and promoting connectedness.

Religious beliefs and practices contribute substantially to the development of personal morality and sound judgment, which influence decisions that shape one's life. Religious education strengthens the formation of moral consciousness through the internalization of religious morality [32]. Internalization, the process wherein an individual adopts the values or regulations prescribed by a religion as their own [33], can affect mental health [34]. Religious moral beliefs such as objections to suicide can also influence suicide rates and attitudes towards suicide [35].

Religious beliefs also affect how individuals deal with stressful situations, suffering, and life problems [36] as it enhances acceptance and one's ability to function competently in the face of stress and adversity [37]. Religious education reinforces religious coping, which is the use of cognitive behavioral techniques to manage stressful situations in light of one's spirituality or religious beliefs [38]. Previous studies have shown that people frequently count on religion to cope with stressful situations $[35,36,39$, 40]. Furthermore, meta-analyses have already indicated the positive impacts of religious coping on health wellbeing [41-43]. Positive religious coping involves engaging in religious practices, seeking social support through religious leaders and congregations, and reframing stressful events in reference to their relationship with God [43-45]. Some of these practices and religious involvement have been proven to help in dealing with stressful situations, anxiety, and isolation, displacement after natural disasters, among others [46]. For example, meditation and yoga have been demonstrated to relieve tension and anxiety and stabilize emotions. Traditionally, studies have examined religious coping among Christian populations. However, ethnic minorities living as long-term residents in Western countries have begun to receive attention. These findings suggest that disempowered and deprived groups, including women and ethnic minorities, resort to the use of religious coping and found great efficacy in it [43]. In addition, religious coping has been shown to be extensively used when situations are deemed uncontrollable $[41,47]$, thus providing an outlet for those at a social disadvantage and with limited access to external resources [48]. Based on these findings, it is apparent that religious coping serves as a resilience mechanism as it enhances a more stable and positive measures of wellbeing. The use of religious coping can enhance contentment with one's life, thus, potentially protecting against the long-term effects of distress [49].

Religious education can likewise serve as a vehicle to emphasize respect for diversity, by providing a venue for adolescents to understand the differences in religions and world views. Social skills are needed to live and work together harmoniously and to function effectively in a diverse society [50]. It is likewise vital to developing good relationships and values and respecting differences at a personal level [51]. By talking about other's beliefs and traditions, students are equipped with social skills and the ability to prevent prejudice and hatred towards others [52]. Exploring issues within and across faiths can teach children and adolescents how to understand and respect different religions, beliefs, values and traditions (including ethical life stances), and their influence on individuals, societies, communities and cultures [53]. Putting emphasis on religious diversity can eventually reduce, if not eliminate, cases of bullying, offensive behavior, and violence [54].

Schools exist not only to provide academic knowledge to students, but also to promote connectedness among its students and teachers. Through religious education, the learning atmosphere can be improved by connecting students regardless of their faith [50]. It has been found that receiving religious education provided students with a higher purpose in life and more social support from peers [55]. It can also be a means for teaching religious beliefs and practices which promote support and care for one another. The social support one receives from being part of religious communities and participating in 
religious practices contributes to positive mental health and well-being [56, 57]. This social support, which accounts largely to the impact of religiosity to well-being, can be credited to the concept of love and brotherhood being promoted by religious teachings [58]. Research has shown that participating in religious practices has positive effects on adolescents in terms of having higher selfesteem and lower incidence of substance abuse through engaging in religious practices, adolescents achieved a feeling of belongingness [22]. Furthermore, social relationships formed through religious involvement are likewise found to intervene with adolescent suicide ideation [59].

Previous studies have also reported some negative effects of religion and religious education on mental health. In some cases, religious beliefs and practices contributed to the development of certain disorders like obsession, anxiety, and depression [60]. In other cases, religiosity was cited as a deterrent in seeking professional help for mental health [61-63]. There are also conflicting findings regarding radicalism and extremism due to religious education. In the case of Pakistan and Indonesia, religious educational institutions were reported to be exploited by perpetrators of extremism $[64,65]$. However, others argue that there is no sufficient evidence to conclude that Islamic education contributes to extremism; on the contrary it is reported to foster civic empowerment among students [66].

Additionally, students who are considered as religious minority are also at risk to developing negative mental health outcomes. For example, non-Christian students attending a school where majority of the population are Christians can experience religious discrimination or microaggressions [67]. A previous study has also found that a religious "mismatch" (i.e. students attending a school with religious education which is different from their religion) increased the risk of suicide attempts and self-harm significantly [68]. Other issues identified by previous studies include concerns about schools as being safe spaces [69].

Aside from negative effects experienced by religious minority, religious education can also negatively impact adolescents who belong to sexual minority groups. As discussed previously, adolescence is an important period of personal development and sexual identity development figures prominently during this stage. However, previous studies have reported negative effects of religious education on lesbian, gay, bisexual, transgender, and queer (or questioning) (LGBTQ) adolescents. Although gender discrimination is not unique to religious schools, hostile messages promoted by religious denominations and groups can foster victimization of LGBTQ adolescents [70-72]. These religiously-based messages of discrimination can contribute to social exclusion. Furthermore, non-acceptance of LGBTQ views (i.e. not accepted or permitted in school work) can also undermine academic achievement [72]. Despite, these unintended negative outcomes, religion remains an important aspect of human life, and if implemented properly, religious education can positively influence adolescent mental health.

\section{Conclusion}

Schools are an effective setting for gathering large populations of adolescents for mental health promotion and it is also important to reflect on the crucial role of religious education on mental health among this age group. School-based mental health education and promotion strategies can maximize the benefits of religious education by putting emphasis on effective implementation of religious education to influence adolescent mental health.

\section{Abbreviations \\ DALY: disability-adjusted life years; LGBTQ: lesbian, gay, bisexual, transgender, and queer (or questioning); YLD: years of life lived with disability; YLL: years of life lost.}

\section{Authors' contributions}

JK conceived the presented idea. CAME and MFTCL wrote the manuscript in consultation with EA, ERG, CRL, and RRQ. All authors read and approved the final manuscript.

\section{Author details \\ ${ }^{1}$ Department of Global Health, School of Health Sciences, University of the Ryukyus, Okinawa, Japan. ${ }^{2}$ Department of Environmental and Occu- pational Health, College of Public Health, University of the Philippines Manila, Manila, Philippines. ${ }^{3}$ Department of Health Promotion and Education, College of Public Health, University of the Philippines Manila, Manila, Philippines. \\ ${ }^{4}$ Faculty of Medicine, Mataram University, Mataram, Indonesia. ${ }^{5}$ Depart- ment of Psychiatry and Behavioral Medicine, College of Medicine, Univer- sity of the Philippines Manila, Manila, Philippines. ${ }^{6}$ Japanese Consortium for Global School Health Research, Nishihara, Japan.}

Acknowledgements

Not applicable.

Competing interests

The authors declare that they have no competing interests.

Availability of data and materials

Not applicable.

Consent for publication

Not applicable.

Ethics approval and consent to participate

Not applicable.

\section{Funding}

This paper was supported by the Research Grant for National Center for Global Health and Medicine (30-3, 30-4). 


\section{Publisher's Note}

Springer Nature remains neutral with regard to jurisdictional claims in published maps and institutional affiliations.

Received: 4 December 2018 Accepted: 22 April 2019

Published online: 26 April 2019

\section{References}

1. Whiteford HA, Ferrari AJ, Degenhardt L, Feigin V, Vos T. The global burden of mental, neurological and substance use disorders: an analysis from the Global Burden of Disease Study 2010. PLoS ONE. 2015. https://doi. org/10.1371/journal.pone.0116820.

2. World Health Organization. Depression and other common mental disorders: global health estimates. World Health Organization; 2017. https ://apps.who.int/iris/bitstream/handle/10665/254610/WHO-MSD-MER2017.2-eng.pdf. Accessed 05 Nov 2018.

3. Sokol JT. Identity development throughout the lifetime: an examination of Eriksonian theory; 2009. http://epublications.marquette.edu/cgi/viewc ontent.cgi?article $=1030 \&$ context $=$ gjcp. Accessed 05 Nov 2018.

4. Elkind D. The origins of religion in the child. Rev Relig Res. 1970;1:35-42.

5. Regnerus MD, Uecker JE. Finding faith, losing faith: the prevalence and context of religious transformations during adolescence. Rev Relig Res. 2006;1:217-37.

6. Kessler RC, Aguilar-Gaxiola S, Alonso J, Chatterii S, Lee S, Ormel J, Üstün TB, Wang PS. The global burden of mental disorders: an update from the WHO World Mental Health (WMH) surveys. Epidemiol Psychiatr Soc. 2009;18(1):23-33.

7. Saxena S, Jané Llopis E, Hosman CM. Prevention of mental and behavioral disorders: implications for policy and practice. World Psychiatry. 2006;5(1):5-14.

8. Barry MM, Clarke AM, Jenkins R, Patel V. A systematic review of the effec tiveness of mental health promotion interventions for young people in low and middle income countries. BMC Public Health. 2013. https://doi org/10.1186/1471-2458-13-835.

9. Das JK, Salam RA, Lassi ZS, Khan MN, Mahmood W, Patel V, Bhutta ZA. Interventions for adolescent mental health: an overview of systematic reviews. J Adolesc Health. 2016. https://doi.org/10.1016/j.jadohealth 2016.06.020.

10. Katz C, Bolton SL, Katz LY, Isaak C, Tilston-Jones T, Sareen J, Swampy Cree Suicide Prevention Team. A systematic review of school-based suicide prevention programs. Depress anxiety. 2013. https://doi.org/10.1002/ da.22114.

11. Schreiner P. Towards a European oriented religious education. Towards religious competence: diversity as a challenge for education in Europe. Munster: Lit Verlag; 2001. p. 253-67.

12. Federspiel HM. Pesantren. In: The Oxford Encyclopedia of the Islamic World. Oxford Islamic Studies Online. http://www.oxfordislamicstudies .com/print/opr/t236/e0632. Accessed 09 Oct 2018.

13. Garrone GM. The Catholic School. In: The Sacred Congregation for Catholic Education; 1977. http://www.vatican.va/roman_curia/congregati ons/ccatheduc/documents/rc_con_ccatheduc_doc_19770319_catho lic-school en.html. Accessed 09 Oct 2018.

14. Bråten $\mathrm{OM}$. A comparative study of religious education in state schools in England and Norway; 2009. http://wrap.warwick.ac.uk/3122/. Accessed 09 Oct 2018.

15. Bobinac AM. Comparative Analysis of Curricula for Religious Education: Examples of Four Catholic Countries; 2007. https://pdfs.semanticscholar .org/cd32/1d76ce93f52735b146d4840673ebf3ea6f68.pdf. Accessed 09 Oct 2018

16. Coleman EB, White $K$, editors. Religious tolerance, education and the curriculum; 2011. https://www.sensepublishers.com/media/881-relig ious-tolerance-education-and-the-curriculum.pdf. Accessed 08 Apr 2019.

17. Vermeer P. Religious education and socialization. Relig Educ. 2010. https ://doi.org/10.1080/00344080903472774.

18. Hoffmann NW. Teaching Religion in Secular Schools. Relig Educ. 1980;75(6):667-81.
19. Hilliard $\mathrm{FH}$. The influence of religious education upon the development of children's moral ideas. Br J Educ Psychol. 1959. https://doi. org/10.1111/j.2044-8279.1959.tb01474.x

20. Myers SM. An interactive model of religiosity inheritance: The importance of family context; 1996. http://www.psychology.hku.hk/ftbcstudies/churc h/images/docs/Myers_1996.pdf. Accessed 09 Nov 2018.

21. Smith C, Denton ML. Adolescent religion and life outcomes. In: Soul searching: the religious and spiritual lives of American teenagers. Oxford: Oxford University Press. 2009; https://doi.org/10.1093/019518095x .003 .0008 .

22. Wong YJ, Rew L, Slaikeu KD. A systematic review of recent research on adolescent religiosity/spirituality and mental health. Issues in mental health nursing; 2006. https://www.researchgate.net/profile/Y_Joel_ Wong/publication/7354505_A_systematic_review_of_recent_resea rch_on_adolescent_religiosityspirituality_and_mental_health/links /54bd4b680cf27c8f2814b51a.pdf. Accessed 09 Nov 2018.

23. Hill PC, Pargament Kl, Hood RW, McCullough JM, Swyers JP, Larson DB, Zinnbauer BJ. Conceptualizing religion and spirituality: points of commonality, points of departure. J Theory Soc Behav. 2000. https://doi. org/10.1111/1468-5914.00119.

24. King PE, Boyatzis CJ. Exploring adolescent spiritual and religious development: Current and future theoretical and empirical perspectives. Appl Dev Sci. 2004. https://doi.org/10.1207/s1532480xads0801_1.

25. Gonçalves JP, Lucchetti G, Menezes PR, Vallada H. Religious and spiritual interventions in mental health care: a systematic review and meta-analysis of randomized controlled clinical trials. Psychol Med. 2015. https://doi. org/10.1017/s0033291715001166.

26. Assad S, Niazi AK, Assad S. Health and Islam. J Midlife Health. 2013. https //doi.org/10.4103/0976-7800.109645.

27. Harvey C. A Buddhist perspective on Health and Spirituality; 2013. http://journals.equinoxpub.com/HSCC/article/download/16921/13195. Accessed 05 Nov 2018

28. DorffE. The Jewish tradition: religious beliefs and healthcare decisions. http://www.trinityhealth.org/documents/Ethics/4\%20Religious\%20Tra ditions/Judaism/Jewish\%20l.pdf. Accessed 09 Oct 2018.

29. Harper WA. The major objectives of religious education. Relig Educ. 1937. https://doi.org/10.1080/0034408370320407.

30. Isralowitz R, Reznik A. Impact of religious education and religiosity on adolescent alcohol use and risk-taking behavior. Relig Educ. 2015. https:// doi.org/10.1080/00344087.2015.1039388.

31. Eskin M. The effects of religious versus secular education on suicide ideation and suicidal attitudes in adolescents in Turkey. Soc Psychiatry Psychiatr Epidemiol. 2004. https://doi.org/10.1007/s00127-004-0769-x.

32. Ryan RM, Rigby S, King K. Two types of religious internalization and their relations to religious orientations and mental health; 1993. https:// www.researchgate.net/profile/Richard_Ryan2/publication/14787962_ Two_Types_of_Religious_Internalization_and_Their_Relations_to_Relig ious_Orientations_and_Mental_Health/links/000b7d529de10ca2cea00 0000.pdf. Accessed 05 Nov 2018.

33. Mazidi M, Ostovar S. Effects of religion and type of religious internalization on the mental health of Iranian adolescents. Percept Mot Skills. 2006. https://doi.org/10.2466/pms.103.1.301-306.

34. Pajević I, Hasanović M, Delić A. The influence of religious moral beliefs on adolescents' mental stability; 2007. https://s3.amazonaws.com/ academia.edu.documents/5691692/dnb19 3 173-183.pdf?AWSAc cessKeyld=AKIAIWOWYYGZ2Y53UL3A\&Expires $=1554717615 \&$ Signa ture $=\mathrm{OB} \times Z \mathrm{ZcMW}$ wmlcOi5ihPtaU6nWIRFs\%3D\&response-content-dispo sition=inline\%3B\%20filename\%3DThe_Influence_of_Religious_Moral _Beliefs.pdf. Accessed 05 Nov 2018.

35. Koenig HG. Research on religion, spirituality, and mental health: a review. Can J Psychiatry. 2009;54(5):283-91.

36. Joshi S, Kumari S, Jain M. Religious belief and its relation to psychological well-being. J Indian Acad Appl Psychol. 2008. http://medind.nic.in/jak/ t08/i2/jakt08i2p345.pdf. Accessed 05 Nov 2019.

37. Srivastava K. Positive mental health and its relationship with resilience. Ind Psychiatry J. 2011. https://doi.org/10.4103/0972-6748.102469.

38. Pargament KI. The psychology of religion and coping: theory, research, practice. New York: Guilford Press; 2001.

39. Ellison CG, Boardman JD, Williams DR, Jackson JS. Religious involvement, stress, and mental health: findings from the 1995 Detroit Area Study. Soc Forces. 2001. https://doi.org/10.1353/sof.2001.0063. 
40. Weber SR, Pargament KI. The role of religion and spirituality in mental health. Curr Opin Psychiatry. 2014. https://doi.org/10.1097/yco.00000 00000000080 .

41. Ano GG, Vasconcelles EB. Religious coping and psychological adjustment to stress: a meta-analysis. J Clin Psychol. 2005. https://doi.org/10.1002/ jclp.20049.

42. Harrison OM, Koenig HG, Hays JC, Eme-Akwari AG, Pargament KI. The epidemiology of religious coping: a review of recent literature. Int Rev Psychiatry. 2009. https://doi.org/10.1080/09540260124356.

43. Pargament Kl, Smith BW, Koenig HG, Perez L. Patterns of positive and negative religious coping with major life stressors. J Sci Study Relig. 1998;1:710-24.

44. Boudreaux E, Catz S, Ryan L, Amaral-Melendez M, Brantley PJ. The ways of religious coping scale: reliability, validity, and scale development. Assessment. 1995;2(3):233-44

45. Krägeloh CU, Chai PP, Shepherd D, Billington R. How religious coping is used relative to other coping strategies depends on the individual's level of religiosity and spirituality. J Relig Health. 2012. https://doi.org/10.1007/ s10943-010-9416-x.

46. Moreira-Almeida A, Lotufo Neto F, Koenig HG. Religiousness and mental health: a review. Braz J Psychiatry. 2006. https://doi.org/10.1590/s1516 $-44462006005000006$.

47. Adam Z, Ward C. Stress, religious coping and wellbeing in acculturating Muslims. J Muslim Ment Health. 2016. https://doi.org/10.3998/ jmmh.10381607.0010.201.

48. Heisel MJ, Flett GL. Purpose in life, satisfaction with life, and suicide ideation in a clinical sample. J Psychopathol Behav Assess. 2004. https://doi. org/10.1023/b:joba.0000013660.22413.e0.

49. Manea AD. Influences of religious education on the formation moral consciousness of students. Procedia Soc Behav Sci. 2014. https://doi. org/10.1016/j.sbspro.2014.08.203.

50. Liagkis, ML. Teaching Religious Education in Schools and Adolescents' Social and Emotional Development. An Action Research on the Role of Religious Education and School Community in Adolescents' Lives; 2016. https://www.researchgate.net/publication/294888421_Teaching_Relig ious_Education_in_Schools_and_Adolescents'_Social_and_Emotional_ Development_An_Action_Research_on_the_Role_of_Religious_Educa tion_and_School_Community_in_Adolescents'_Lives. Accessed 03 Apr $201 \overline{9}$.

51. Erricker C. Religious education and social and emotional aspects of learning. In: The religious education CPD handbook. http://www.re-handbook. org.uk/section/curriculum/spiritual-moral-and-related-aspects-of-relig ious-education/religious-education-and-social-and-emotional-aspec ts-of-learning-seal. Accessed 9 Oct 2018.

52. Moore JR. Why religious education matters: the role of Islam in multicultural education. Multicult Perspect. 2009. https://doi.org/10.1080/15210 960903116563

53. White J. Should religious education be a compulsory school subject? Brit J Relig Educ. 2004. https://doi.org/10.1080/01416200420042000181929.

54. Johnson P. Religion equity in schools - protecting students and their civil rights. https://www.idra.org/resource-center/religion-equity-in-schoo Is-protecting-students-and-their-civil-rights/. Accessed 17 Nov 2018.

55. Francis LJ, Penny G, Baker S. Defining and assessing spiritual health: a comparative study among 13-to 15-year-old pupils attending secular schools, Anglican schools, and private Christian schools in England and Wales. Peabody J Educ. 2012. https://doi.org/10.1080/01619 56x.2012.679590.

56. Seybold KS, Hill PC. The role of religion and spirituality in mental and physical health. Curr Dir Psychol Sci. 2001. https://doi.org/10.1111/14678721.00106 .

57. Strawbridge WJ, Shema SJ, Cohen RD, Kaplan GA. Religious attendance increases survival by improving and maintaining good health behaviors, mental health, and social relationships. Ann Behav Med. 2001. https://doi. org/10.1207/s15324796abm2301_10.
58. Argyle M. Causes and correlates of happiness. In: Kahneman D, Diener E, Schwarz N, editors. Well-being: the foundations of hedonic psychology. New York: Russell Sage Foundation; 1999. p. 353-73.

59. Nooney JG. Religion, stress, and mental health in adolescence: Findings from add health. Rev Relig Res. 2005. https://doi.org/10.2307/3512165.

60. Park JI, Hong JP, Park S, Cho MJ. The relationship between religion and mental disorders in a Korean population. Psychiatry Investig. 2012. https ://doi.org/10.4306/pi.2012.9.1.29.

61. Haynes TF. Religious beliefs, attitudes towards mental health treatment, and mental health utilization among rural African Americans. https:// deepblue.lib.umich.edu/bitstream/handle/2027.42/78964/thaynesz_1. pdf? sequence=1. Accessed 09 Oct 2018.

62. Bullock M, Nadeau L, Renaud J. Spirituality and religion in youth suicide attempters' trajectories of mental health service utilization: the year before a suicide attempt. J Can Acad Child Adolesc Psychiatry. 2012;21(3):186

63. Rogers-Sirin L, Yanar C, Yüksekbaş D, Senturk MI, Sirin S. Religiosity, cultural values, and attitudes toward seeking psychological services in Turkey. J Cross-Cult Psychol. 2017. https://doi.org/10.1177/0022022117 732532.

64. Afrianty D. Islamic education and youth extremism in Indonesia; 2012. https://www.researchgate.net/profile/Dina_Afrianty/publication/27192 6520_Islamic_education_and_youth_extremism_in_Indonesia/links /5ab1e6d8a6fdcc1bc0bff81b/Islamic-education-and-youth-extremismin-Indonesia.pdf. Accessed 03 Apr 2019.

65. Shah SS. Religious education and extremism in Pakistan: from Deobandi militancy to a rising Sufi fanaticism; 2018. https://jecs.pl/index.php/jecs/ article/download/10.15503jecs20181.11.26/271. Accessed 03 Apr 2019.

66. Woodward M, Rohmaniyah I, Amin A, Coleman D. Muslim education, celebrating Islam and having fun as counter-radicalization strategies in Indonesia. Perspect Terror. 2010:4(4):28-50.

67. Dupper DR, Forrest-Bank S, Lowry-Carusillo A. Experiences of religious minorities in public school settings: findings from focus groups involving Muslim, Jewish, Catholic, and Unitarian Universalist youths. Children \& Schools. 2015. https://academic.oup.com/cs/article-pdf/37/1/37/87179 29/cdu029.pdf. Accessed 04 Apr 2019.

68. Young $\mathrm{R}$, Sweeting $\mathrm{H}$, Ellaway A. Do schools differ in suicide risk? The influence of school and neighbourhood on attempted suicide, suicidal ideation and self-harm among secondary school pupils. BMC Public Health. 2011. https://doi.org/10.1186/1471-2458-11-874.

69. Jaschok M, Chan HM. Education, gender and Islam in China: The place of religious education in challenging and sustaining 'undisputed traditions'among Chinese Muslim women. Int J Educ Dev. 2009. https://doi. org/10.1016/j.ijedudev.2009.04.004.

70. Higa D, Hoppe MJ, Lindhorst T, Mincer S, Beadnell B, Morrison DM, Wells EA, Todd A, Mountz S. Negative and positive factors associated with the well-being of lesbian, gay, bisexual, transgender, queer, and questioning (LGBTQ) youth. Youth Soc. 2014; https://doi.org/10.1177/0044118×12 449630. https://www.researchgate.net/profile/Peter_Newman12/publi cation/273507298_A_Social_Ecology_of_Bias-Based_Bullying_of_Sexua I_and_Gender_Minority_Youth_Toward_a_Conceptualization_of_Conve rsion_Bullying/links/5a0de81 c0f7e9b7d4dba54d8/A-Social-Ecolo gy-of-Bias-Based-Bullying-of-Sexual-and-Gender-Minority-Youth-Towar d-a-Conceptualization-of-Conversion-Bullying.pdf. Accessed 04 Apr 2019.

71. Maher MJ. Homophobic bullying in Catholic high schools: Five US studies in heterosexism, authority, masculinity, and religion. In: Gender, religion and education in a chaotic postmodern world 2013. Dordrecht: Springer. p. 271-284.

72. Newman PA, Fantus S, Woodford MR, Rwigema MJ. "Pray That God Will Change You": the religious social ecology of bias-based bullying targeting sexual and gender minority youth-a qualitative study of service providers and educators. J Adolesc Res. 2018. https://doi.org/10.1177/07435 58417712013. 